\title{
Market-Based Approaches to Quality Assessment and Management of Higher Education in the Republic of Kazakhstan
}

\author{
Zarina Valikhanova ${ }^{1}$ \\ ${ }^{1}$ Al-Farabi Kazakh National Univesrity, Almaty, Kazakhstan \\ Correspondence: Zarina Valikhanova, al-Farabi Kazakh National Univesrity, Almaty, Kazakhstan. E-mail: \\ info@kaznu.kz
}

Received: June 8, 2015 Accepted: July 11, 2015 Online Published: November 25, 2015

doi:10.5539/ies.v8n12p85 URL: http://dx.doi.org/10.5539/ies.v8n12p85

\begin{abstract}
This article considers the problems of the definition of quality in the educational sphere. Alternative approaches to the concept of quality of education and its evaluation are determined given the different approaches of scientists and experts. The most important criteria in assessing the quality is distinguished and formed in the matrix for quality control and to further enhance the higher education institutions. For the formation of the quality policy as it is conventionally defined in the market environment, interested parties are considered in the quality of education. The article shows an example of quality environment, you can analyze and generate a correct policy of higher education institution, taking into account the market environment and the matrix quality can complement each other in the process of quality management education. The article also discusses the current situation in the market of educational services of the Republic of Kazakhstan, based on the data that are not presented in the article. It is invited to consider the quality index which is formed on the basis of analysis of the "price-quality".
\end{abstract}

Keywords: quality, quality management, quality of higher education, quality management education, human resources, quality management processes

\section{Introduction}

In market terms the question of quality is a priority for the company (Nussbaum \& Sen, 1993). Nowadays, entrepreneurs seriously study the issues of implementation of quality management system in enterprises, which indicates its high relevance. The concept of quality refers to more philosophical category, evidenced by the fact that more than 2,000 years, scientists are prospecting clear definition of the concept. If you have previously distinguished on the basis of the quality of "good-bad", or identified as a high quality, expensive, in the last century to this concept more suited expanded in terms of the wording on the various aspects.

\section{Method}

Evaluation of quality depends on various aspects and conditions of its formation (Boler \& Chambers, 1977). If we say that the quality relates more to the philosophical aspects, then we can never really and objectively evaluate the quality of an item or service. The most obvious form of quality category is expressed in the technical aspect. Here quality is due to the quantitative and qualitative characteristics of the object. In this aspect, the comparison is not clearly expressed only in the aggregate, but in details of the object. Object of research is technical patterns in the formation and manifestation of physical and other properties of objects of the same destination. The economic aspect of the concept of quality as well as philosophical and has no clear boundaries. From an economic point of view it is important to know how the quality corresponds to the needs, otherwise not all high quality is good. In this connection, we will always observe the contradiction between the technical and economic aspects, while both should be used in parallel. The legal aspect is more controlling than formative. The legal aspects of quality act as a set of object properties that satisfy the requirements specified in technical standards (Valdman, 2009).

Despite the different views and aspects, the quality in our time has gained significant phenomenon in human activities. Maybe it is the quality of certain human needs. If we talk about the needs we consider the basic theories, where the lowest level of need is food, security and higher - respect and social importance. Everywhere, on every level, in order to have growth, satisfaction of the needs of the high-level quality is required, after which 
there is a growing demand.

As is known, each object includes a multitude of properties, and together they constitute a quality, but specific characteristics of the product quality of this set emit only those which are currently in the interest of the user. In this connection, the concept of quality is related to the degree of satisfaction of the specific needs of an individual or society.

Approaches to the concept of quality of certain time:

Famous specialist in the field of quality Shewhart (1931) gave the concept of quality two aspects: on the one hand - the objective physical characteristics of the subject, on the other-a subjective category-how the subject is "good." Japanese scientist Isikava (1985) and American Juran (1993) invested in the concept of "quality-the degree of satisfaction of the needs of the consumer products."

Despite the diversity of views, quality on practice is seen as some sort of one major, the dominant feature, most clearly characterizes the object or phenomenon. All the other properties of the object or process, as less important, are not taken into account. This makes it easier to control the quality of abstracting from a number of properties of an object or process (Azgaldov \& Rayhman, 1972).

In addition to the above definitions of the concept of quality by international standards, there are also others. Pirsig (1974), American philosopher and writer, calls the quality final, and therefore not amenable to a certain category of analysis. By R. Persing, quality-the fundamental principle of the tangible and intangible world, and therefore, in principle, cannot be determined (eg, "point") (Kvitko, 2005).

\section{Results}

\subsection{Quality Control}

People approached the issue of quality management since the ancient times. The results of the quality control we see from the ancient basis of the surviving objects (monuments) of ancient culture. And the evidence is captured in wall paintings, which describes the quality management process. In those days, the issue of quality was treated more specifically; there was no doubt that the manufactured items may not be of high quality, in this context the suitability of using the object.

Different concepts and theories began to appear with the advent of production. Deming (1982), Juran (2010), Feigenbaum (1977), Shewhart (1931) as well as Crosby (1979) etc. are considered as the founders and gurus in the field of quality management. Each of them developed his theory of quality management, which we use to this day. The process of development of the concept of quality management, we can provide in the form of a table (Table 1), decided to allocate four interrelated phases such as rejection, quality control, control of quality management and quality management. 
Table 1. Stages of development of a quality management

\begin{tabular}{|c|c|c|}
\hline Time & Name & Concept \\
\hline $\begin{array}{l}\text { XIX century. } \\
70 \text { years }\end{array}$ & $\begin{array}{l}\text { Rejection } \\
\text { Taylor system }\end{array}$ & $\begin{array}{l}\text { The consumer should receive only acceptable products, those that } \\
\text { correspond the standards, another ones shall be discarded }\end{array}$ \\
\hline $\begin{array}{l}\text { Beginning of } \\
\text { XX century. }\end{array}$ & Control of quality & $\begin{array}{l}\text { When we save the previous concept, the focus is on the management of } \\
\text { production processes, increasing the percentage of acceptable products }\end{array}$ \\
\hline $\begin{array}{l}\text { XX century. } \\
50 s-90 s\end{array}$ & Quality control & $\begin{array}{l}\text { Improvement of the entire system of quality management in general, not } \\
\text { in its individual elements, processes, training of all staff to ensure the } \\
\text { quality of the basic methods and their motivation to high quality work, on } \\
\text { the direct involvement of senior management of the company. }\end{array}$ \\
\hline $\begin{array}{l}\text { XX century. } \\
60 \text { - our time }\end{array}$ & $\begin{array}{l}\text { Management of } \\
\text { quality }\end{array}$ & Complete customer satisfaction \\
\hline $60-s$ & \multicolumn{2}{|c|}{ Universal guide quality } \\
\hline \multirow{2}{*}{$80-\mathrm{s}$} & $\begin{array}{l}\text { International } \\
\text { quality standard } \\
\text { ISO series }\end{array}$ & $\begin{array}{l}\text { Allocated separate functional areas. There is a merging of general } \\
\text { management and control of quality, quality management is formed. }\end{array}$ \\
\hline & $\begin{array}{l}\text { TQM (Total quality } \\
\text { management) }\end{array}$ & $\begin{array}{l}\text { An integrated approach provides progressive and systematic improvement } \\
\text { of all aspects of the organization's activities, intensive and consistent use } \\
\text { of certain methods, tools and resources }\end{array}$ \\
\hline
\end{tabular}

Compiled by the author based on the source (Yershow, 2008)

The emergence of these concepts led to the better creation of products and better with the better quality, and the cost of the outlay of quality control is also reduced. However, it should be noted that despite all the positive aspects of the development of the concepts of quality management, we somehow become witnesses of economic, financial and even political crises. Despite the fact that all the goods are always sold, the company is not always successful. What can we expect next? Nobody asks whether there will be further development of quality management. That is, the creation of new concepts or forms in quality assessment and management. Maybe the data needs to be focused on the concept of macro effect of human development?

\subsection{Quality of Education}

The official website of UNESCO stated that education plays a major role in the formation and development of the human personality, economic growth and the strengthening of social ties. At the same time it is - an important tool for fighting poverty and one of the pillars of sustainable development.

Quality of education - a measure of the relative height levels:

- Technology of transfer of knowledge, skills and technologies of educational work;

- The effectiveness of the current perception of the components of the pedagogical process;

- Efficiency of obtaining professional and non-professional competencies by students.

The policy document UNESCO (1995) "reform and development of higher education" education quality assessment includes three aspects: the quality of staff and programs, quality of infrastructure and the quality of the students learning environment (Loginova, 2009).

The average educated people live in prosperity and the unemployment among the educated people is lower, and if educated are unemployed, the more often they are temporarily unemployed.

In the process of globalization, we are faced with the problems of unification of the system of higher education. One reason is the migration of the labor force, as well as openness to business and academic mobility. In this connection, the majority of universities and governments appear some questions to an objective assessment of the quality of education.

One of the mechanisms that guarantee the continuity of the process of improving the quality of higher education, is the establishment of the university effective scheme of administrative actions that establish and maintain links between the following main processes: evaluation - improvement program - realization - evaluation (so-called 
"quality loop» Deming). In this context, the main function of evaluation becomes not so much the fixation of the cash system state, but the definition of a strategy for improving its quality. The quality of university education can be described using the scheme of the system analysis and presented as a unity such as integrated components:

1) The quality of the activity results of the educational system.

2) The quality of the educational system, or the quality of the educational process and the environment.

3) The quality of educational services.

4) The quality management system of education. In turn, each component is specified number of criteria.

\subsection{Criteria for Assessing the Quality of Education}

Number of criteria for evaluating the quality of education can reach tens of hundreds (Cheng \& Tam, 1997). To simplify working with the criteria they are combined in a group. It seemed there was nothing complicated about it, but their evaluation is a complex process. Most often the system of quality assessment approaches in the light of static data of university activity, in expert way finding quality by identifying certain criteria and outcomes.

There are different approaches to creating quality systems and groups of criteria. Considering those groups of criteria, we believe that are relevant:

- The criteria of quality educational content

- Quality criteria staffing

- Quality criteria of learning technologies

- Quality criteria of technical support

- The criteria of quality of learning outcomes

What are the criteria and how to use it is considered by many experts, but by studying the materials we encounter with ballroom-weight evaluation criteria, with a regression analysis of these criteria, etc. The results obtained are naturally taken into account in making certain decisions, but they are more aimed at solving local problems in quality management system than in the solution of systems. From our point of view it is worth to form a matrix of criteria groups to determine their levels of organization which strives to offer high-quality educational services, which in general will improve the quality (Table 2).

Table 2. Matrix quality criteria

\begin{tabular}{|c|c|c|c|c|c|}
\hline \multirow{2}{*}{$\begin{array}{l}\text { Quality } \\
\text { Criteria }\end{array}$} & \multicolumn{5}{|c|}{ Levels of quality } \\
\hline & Low level & Average level & $\begin{array}{c}\text { Above-average } \\
\text { level }\end{array}$ & High level & PRO \\
\hline $\begin{array}{l}\text { The content of } \\
\text { education }\end{array}$ & $\begin{array}{l}\text { Curricula and } \\
\text { programs }\end{array}$ & $\begin{array}{l}\text { Match of } \\
\text { curricula } \\
\text { standards }\end{array}$ & $\begin{array}{l}\text { Compliance } \\
\text { programs market } \\
\text { trends }\end{array}$ & $\begin{array}{c}\text { Ensure their own } \\
\text { teaching } \\
\text { materials }\end{array}$ & $\begin{array}{c}\text { Availability of } \\
\text { professional } \\
\text { programs }\end{array}$ \\
\hline Staff & $\begin{array}{l}\text { Ownership of } \\
\text { IT }\end{array}$ & Qualification & $\begin{array}{c}\text { Availability of } \\
\text { teaching materials }\end{array}$ & Creativity & Ability to lead \\
\hline Technologies & $\begin{array}{l}\text { General } \\
\text { methodics }\end{array}$ & \multicolumn{2}{|c|}{$\begin{array}{l}\text { Conducting lectures and seminars } \\
\text { tests and testing }\end{array}$} & \multicolumn{2}{|c|}{$\begin{array}{c}\text { Conducting laboratory and practica } \\
\text { works }\end{array}$} \\
\hline $\begin{array}{l}\text { Technical } \\
\text { support }\end{array}$ & \multicolumn{3}{|c|}{$\begin{array}{l}\mathrm{PC} \text { equipped classrooms } \\
\text { lability of the required software }\end{array}$} & $\begin{array}{l}\text { Availability of the } \\
\text { network and } \\
\text { access to } \\
\text { information }\end{array}$ & $\begin{array}{l}\text { Availability of } \\
\text { integrated } \\
\text { management } \\
\text { systems }\end{array}$ \\
\hline Results & $\begin{array}{l}\text { Intermediate } \\
\text { control }\end{array}$ & $\begin{array}{l}\text { Results of } \\
\text { control works }\end{array}$ & $\begin{array}{l}\text { Studying the } \\
\text { discipline }\end{array}$ & The final control & $\begin{array}{l}\text { Level of } \\
\text { employment }\end{array}$ \\
\hline
\end{tabular}

Compiled by the author based on the source (Bartasevich, 2008).

Representation of this matrix is useful for determining at what level of quality is one direction or group of criteria and what level must comply with the criteria and the remaining groups. Thus, the content of university 
education is at the highest level, respectively footage should have a creative potential, which promotes the use of conduct laboratory and field practical work, for this must be available communications networks and free access to information (perhaps through the Internet) and libraries, in total this should be reflected in the final control. Final control may be the single state control of knowledge, for example, recently in Kazakhstan initiated TDMA (external evaluation of educational achievements), which is held for graduate students.

\subsection{The Quality of Education in Terms of Its Environment}

Having considered the various qualities of criteria and approaches to its evaluation, we can create system environment stakeholders in improving the quality of education in accordance with their criteria and vision of the quality of education (Figure 1).

Environmental analysis can give more conclusions about the direction in which to develop the quality of higher education. The presented model shows the general ambience of the quality of education. That for narrow profile or technical specialties may be additions to the environment quality.

Here we see the market approach, and the management of quality based on its real understanding. Quality education must satisfy all stakeholders (Kara, 2004). Naturally, with all that we know about quality management, application of standards and international accreditation, have a higher education institution formed or formed its quality policy. Priority for public universities is to assess the quality of government departments and satisfying their standards and vision. Private institutions are focused on the students and parents (Wilkie, 1994). If the lines are connected by the parties concerned, in both cases we see the wrong circles and accordingly placed the centers of gravity in quality management.

\subsection{The Market Situation of Education in the Republic of Kazakhstan}

Before the independence, Kazakhstan had 60 universities in the late 90s their number has reached 180 institutions. This indicator looks illogical especially when you consider that, by the end of the 90's, Kazakhstan's economy has shown some decline. Also it should be noted that during this period a decline in birthrate was recorded. Accordingly, given the strategic development of the company you need to plan its activities for at least 5 years, probably at the opening of the institution in those years were guided by other data and indicators. In the early 2000s, the state had taken measures to tighten the requirements for licensing of educational activities, which led to a reduction in universities, in particular commercial to 149 , this trend saves to this day, and their number is reduced every year (Figure 2). 


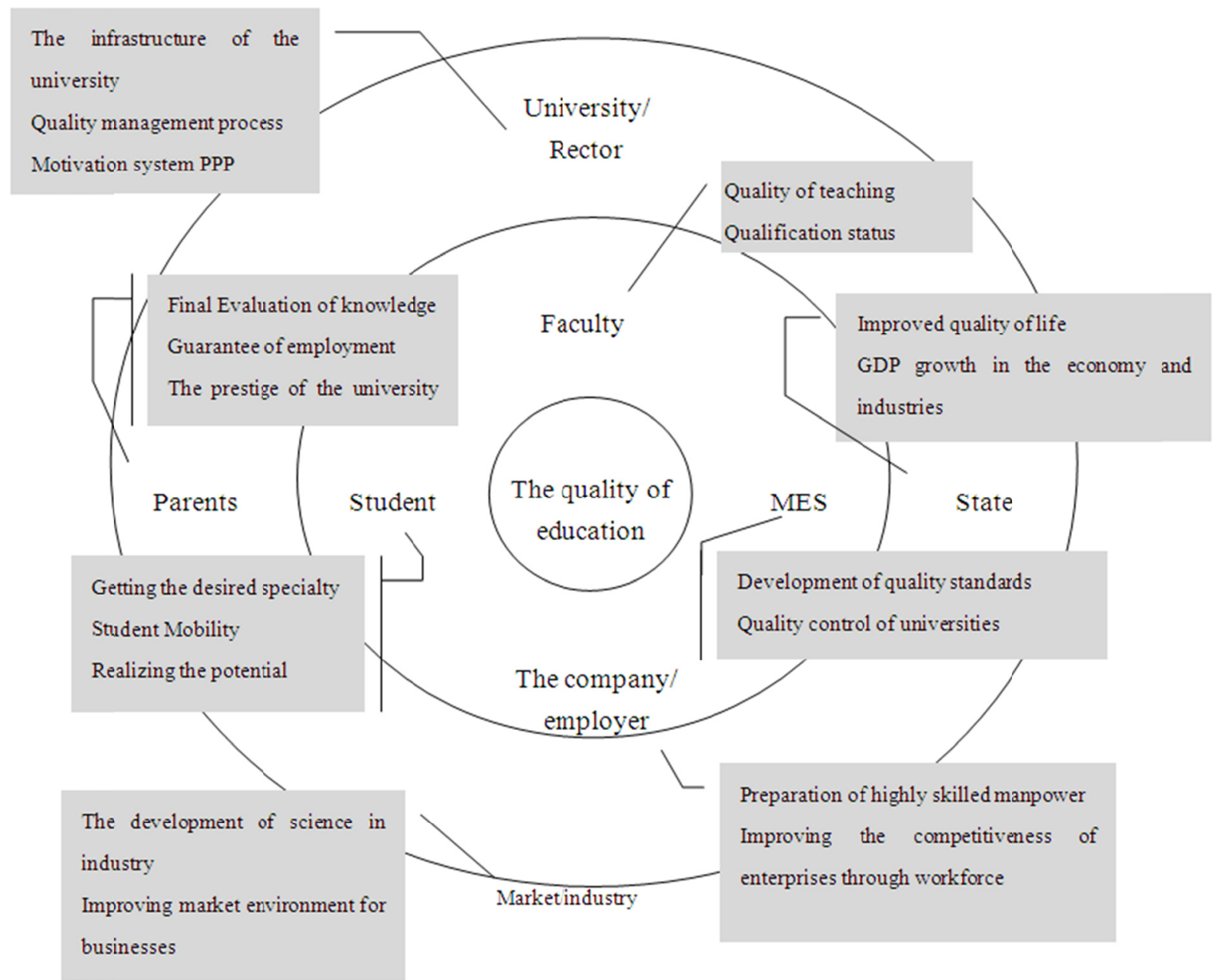

Figure 1. Stakeholders in the management of the quality of education



Figure 2. The dynamic development of the higher education institutions in the Republic of Kazakhstan 
The greatest reduction of institutions we observe in the commercial sector of universities, however, despite this, their share also remains significant and is more than $60 \%$. The founders of private universities of the country are mainly domestic representatives; most of them are from the national education system. Mainly commercial universities prepare specialists in humanities, such as economics, law. This specialization in the 90's was the most popular and therefore the proportion of specialists in Kazakhstan exceeded the humanities, on the other hand labor market conditions consistent with this development.

\subsection{Market Quality Index}

As it is commonly understood than the more the cost, the higher the quality, but the quality of the education system of education involves many factors and aspects, not only the level of teachers' salaries, etc. Analyzing the cost of education and universities, we tried to create a database of indicators of quality index, which is determined by two factors is the number of students per 1 teacher of the University and accordingly on tuition rate in this university (Figure 3).

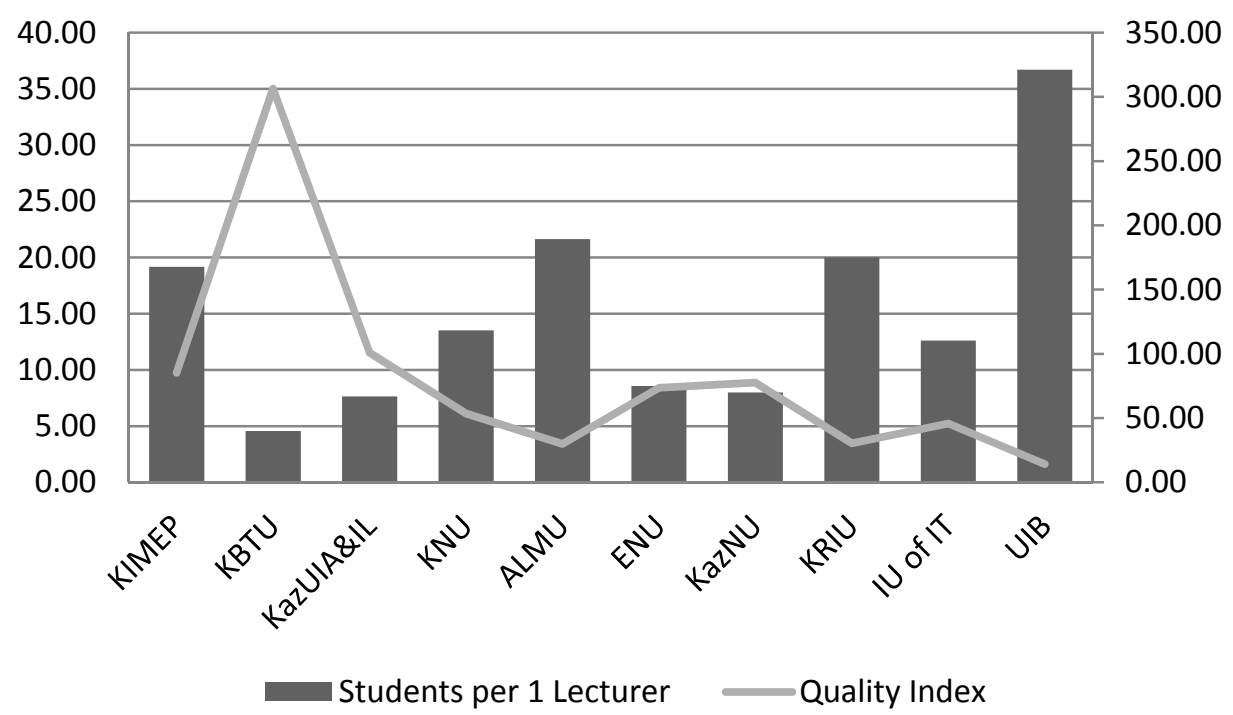

Figure 3. The index of the quality of higher education institutions of Kazakhstan

Based on the chart we see that KBTU (Kazakh-British Technical University) is ahead of analyzed objects, almost by 3 times, with an enrollment of 4 students per 1 teacher. However, it should be noted that KBTU is a technical college and accordingly, the number of students is not great. This analysis shows the state of university quality in principle today that is more than students recruited, the less is paid to quality in the learning process, especially private universities, where the main policy of the company is built on a constant increase in the number of entrants.

In international accreditation as well as in national, contingent faculty staff is recognized, determining the number of hours/credits. But as we know, in order to reduce the costs of employment of the teacher imposed in addition and scientific activities (Tulembayev, Mukasheva, \& Nurlanova, 2014). It turns a conflict of interest, because highly qualified teachers and scientists more efficient in scientific activities than their use in teaching. Thus, on the basis of a simple matrix of price and quality, we see that private institutions are not in a competitive situation, but it is all reflected as a general education system.

\section{Discussion}

In this article, we defined the notion of quality, which is as close to the conditions of operation of the system of higher education. This quality itself includes many aspects and only the technical aspect is defined by the properties and characteristics compared with the other object. The quality of education can be determined by economic growth of the country's economy but it also has many aspects. In this connection, the most approximate determination of quality can serve as meeting the needs of stakeholders.

Quality management as well as the very concept adopts itself to the same aspects. The only thing that can determine the effective quality control is not simple construction of complex models, analysis and control. In this 
connection, our proposed model can serve as a quality matrix of its kind in monitoring to determine the level of quality of its further development. Moreover, this matrix can be used as a local mode for the university and for the government to improve the quality of higher education.

Returning to the questions of satisfaction, we come to the market aspects of the quality of education. In the formation of the desired quality, it is necessary to analyze the stakeholders to improve the quality of their actions and vision in the process of quality management, which directly determines the policies and the concept of the quality of education at the university.

The market situation of education in Kazakhstan shows a unique case. Partly populous country has a large number of universities. On the one hand in the quantitative aspect, we have had some success, on the other hand innovation does not appear and GDP growth is not as swift as for example in other developing countries. Quality index generated from the analysis of the price-quality defines the problems inherent in the state of the market specialists teachers. In Kazakhstan, there is a shortage of highly specialized faculty scientists on one side to ensure steady load of students per instructor, on the other hand to ensure the growth of research and results.

\section{References}

Azgaldov, G., \& Rayhman, A. (1972). About qualimetrics. Publisher of standards, Moscow.

Bartasevich, I. (2008). Criteria system of students' education quality in higher educational institutions. AGTU Journal, 3, 217-222

Boller, E. F., \& Chambers, D. L. (1977). Quality Aspects of Mass-Reared Insects. Environmental Science Research, 11, 219-235. http://dx.doi.org/10.1007/978-1-4684-2871-1_7

Cheng, Y. C., \& Tam, W. M. (1997). Multi-models of quality in education. Quality Assurance in Education, 5(1), 22-31. http://dx.doi.org/10.1108/09684889710156558

Crosby, P. (2014). Quality is Free: The Art of Making Quality Certain. McGraw-Hill, p.309

Defeo, J., \& Juran, J. (2010). Juran's Quality Handbook: The Complete Guide to Performance Excellence (6th ed.). McGraw Hill Professional.

Deming, W. (1982). Quality, productivity, and competitive position. Massachusetts Institute of Technology, Center for Advanced Engineering Study.

Feigenbaum, A. V. (1977). Quality and Productivity. Quality Progress, Nov., 18-21.

Isikava, K. (1985). What Is Total Quality Control? The Japanese Way. Prentice Hall.

Juran, J. (1993). All of quality: Foreign experience (2nd ed.). Moscow.

Kara, A. (2004). Business student satisfaction, intentions and retention in higher education: An empirical investigation. Pennsylvania State University-York Campus Oscar W. DeShields, Jr., California State University, Northridge.

Kvitko, A. (2005). Quality management. Tutorial. State university of economic, statistics and information, Moscow.

Loginova, V. (2009). The influence of education on the competitiveness of economic systems. Problems of Modern Economics, 2(30).

Nussbaum, M., \& Sen, A. (1993). The Quality of Life. Clarenton Press. http://dx.doi.org/10.1093/0198287976.001.0001

Pirsig, R. (1974). Zen and the Art of Motorcycle Maintenance. William Morrow \& Company.

Shewhart, W. (1931). Economic control of quality of manufactured product. D. Van Nostrand Company.

Tulembayev, A., Mukasheva, S., \& Nurlanova, N., (2014). Development and project team building and its impact on the increase in market value of the project. Journal of Business and Economics, 5(9), 1647-1655.

UNESCO. (1995). Reform and Development of Higher Education. Program Document, Paris,

Valdman, I. (2009). Key aspects of the quality of education: lessons from international experience. Moscow centre of education quality.

Wilkie, W. L. (1994). Consumer Behavior (3rd ed.). New York: Jhon Wiley \& Sons Inc.

Yefremov, A. (2008). Quality management system in PFUR. PFUR, Moscow.

Yershov, A. (2014). Quality Management. Litres, Moscow. 


\section{Copyrights}

Copyright for this article is retained by the author(s), with first publication rights granted to the journal.

This is an open-access article distributed under the terms and conditions of the Creative Commons Attribution license (http://creativecommons.org/licenses/by/3.0/). 